\title{
Edukasi Suplemen Herbal Untuk Menjaga Imun dan Daya Tahan Tubuh Bagi Pedagang di Kota Meulaboh
}

\author{
Hasanuddin Husin', Teuku Athaillah*2 \\ 1Program Studi Teknologi Hasil Pertanian, Fakultas Pertanian, Universitas Teuku Umar \\ 2Program Studi Agribisnis, Fakultas Pertanian, Universitas Teuku Umar \\ *e-mail: hasanuddinhusin@utu.ac.id ${ }^{1}{ }_{\llcorner}$athaillah.teuku@utu.ac.id ${ }^{2}$
}

\begin{abstract}
To maintain the health condition of vegetable traders and street vendors in Meulaboh, supplements are needed to reinforce their immune system. Traders must be able to maintain their immune system so they are not susceptible to disease and the Covid19 virus. The purpose of this service activity is to teach traders how to make herbal supplements. The methods for implementing the service are: (1) Socialization concerning Covid19 and its prevention by strengthening immunity. (2) Socialization of the importance of consuming herbal supplements to the traders (3) Process for making herbal supplements. The community welcomes this service, as the traders are completely enthusiastic and want to make the herbal supplements at home. The enthusiasm of traders can also be noticed from their curiosity about how to make the herbal supplements. This service program is certainly very useful for traders to maintain immunity and body resistance during the COVID-19 pandemic.
\end{abstract}

Keywords: covid 19; herbs; supplement

\begin{abstract}
Abstrak
Untuk menjaga kondisi kesehatan para pedagang sayur dan pedagang kaki lima di Meulaboh, diperlukan suplemen untuk menjaga daya tahan tubuh bagi para pedagang sayur dan pedagang kaki lima. Para pedagang harus bisa menjaga imun tubuh agar tidak mudah terserang penyakit dan virus Covid 19. Tujuan kegiatan pengabdian ini adalah untuk mengajarkan cara pembuatan suplemen herbal kepada para pedagang. Adapun Metode pelaksanaan Pengabdian adalah: (1) Sosialisasi tentang covid 19 dan pencegahannya dengan menguatkan imun (2) Sosialisasi pentingnya meminum suplemen herbal kepada pedagang (3) Proses Pembuatan suplemen herbal. Masyarakat menyambut baik pengabdian ini. Para pedagang sangat antusias dan ingin membuat suplemen herbal dirumah. Antusias pedagang juga terlihat dari keingintahuan pedagang tentang cara pembuatan suplemen herbal. Program pengabdian ini tentunya sangat bermanfaat bagi para pedagang untuk menjaga imun dan daya tahan tubuh pada saat pandemi covid 19 melanda.
\end{abstract}

Kata kunci: covid 19; herbal; suplemen,

\section{PENDAHULUAN}

Pandemi Covid 19 menyebabkan berbagai masalah ekonomi bagi masyarakat di semua sektor. Dampak dari pandemi bukan hanya dirasakan oleh perusahaan-perusahaan besar, pedagang-pedagang kecil pun turut terkena imbas dari pandemi covid 19. Dampak langsung yang dirasakan oleh pedagang-pedagang kecil diantaranya menurunnya pembeli disaat pandemi Covid 19, menurunnya pendapatan pedagang, dan yang paling ditakuti pedagang adalah tertularnya covid 19 dari pembeli yang tidak dikenal kepada pedagang.

Pandemi Covid 19 terus meluas di Aceh. Berikut ini adalah data pasien positif Covid 19 yang di ambil dari Dinas Kesehatan Aceh (https://dinkes.acehprov.go.id) hingga tanggal 17 Agustus 2021 telah mencapai 28.164 orang. Pasien yang sedang dirawat sebanyak 5.617 orang. Pasien yang sembuh (penyintas Covid-19) telah mencapai 21.345 orang. Sedangkan kasus meninggal dunia secara akumulatif sudah mencapai 1.202 orang.

Kasus kumulatif tersebut sudah termasuk kasus konfirmasi baru harian yang bertambah lagi hari ini sebanyak 390 orang. Pasien yang sembuh bertambah 218 orang, dan penderita Covid19 yang meninggal dunia bertambah 12 orang. Penderita baru 390 orang tersebut, meliputi warga 
Banda Aceh 102 orang, Aceh Besar 54 orang, Pidie 51 orang, Aceh Tamiang 39 orang, Lhokseumawe 28 orang, Aceh Singkil 18 orang, Langsa 15 orang, Bireuen 13 orang, dan warga Aceh Utara sebanyak 11 orang. Kemudian warga Aceh Barat sembilan orang, warga Simeulue dan Aceh Selatan sama-sama tujuh orang. Selanjutnya Aceh Jaya enam orang, warga Pidie Jaya, Sabang, dan Subulussalam, masing-masing lima orang. Lebih lanjut warga Aceh Timur empat orang dan Gayo Lues tiga orang. Sementara warga Aceh Tengah, Nagan Raya, dan Aceh Barat Daya, samasama dua orang. Sedangkan warga Aceh Tenggara dan Bener Meriah masing-masing satu orang.

Pasien covid 19 bisa akan terus bertambah apabila imun dan daya tahan tubuh masyarakat lemah sehingga menjadi sangat mudah terpapar virus. Bukan hanya bertambahnya jumlah masyarakat yang terpapar Covid 19, tetapi yang lebih ditakutkan adalah bertambahnya tingkat mortalitas (kematian) yang disebabkan oleh virus Covid 19.

Pandemi corona menyebabkan berbagai kendala bagi pedagang sayur dan pedagang kaki lima dalam menjalankan usahanya. Ketakutan tertularnya Covid 19 membuat pedagang sangat was-was dalam berjualan. Pedagang sayur dan pedagang kaki lima sangat beresiko untuk tertularnya Covid 19 karena banyaknya pembeli yang dijumpai setiap harinya. Pedagang tidak bisa membedakan pembeli yang tertular Covid 19 ataupun yang tidak.

Banyak pedagang sayur dan pedagang kaki lima di kota Meulaboh yang sudah tua dan rentan terserang Covid 19. Pedagang tersebut harus terus berdagang walaupun dalam kondisi apapun demi mencari rezeki untuk menyambung hidup. Pedagang-pedagang tersebut harus tetap mengambi resiko berjualan walaupun sangat rentan terserang Covid 19.

Untuk menjaga kondisi kesehatan para pedagang sayur dan pedagang kaki lima di Meulaboh, diperlukan suplemen untuk menjaga daya tahan tubuh bagi para pedagang sayur dan pedagang kaki lima. Para pedagang harus bisa menjaga imun tubuh agar tidak mudah terserang penyakit dan virus terutama Covid 19.

\section{Tujuan Kegiatan}

Untuk mengedukasi cara pembuatan suplemen herbal kepada para pedagang agar bisa menjaga imun daya tahan tubuh.

\section{Kajian Literatur}

Suplemen herbal merupakan salah satu produk yang menjadi asupan antioksidan alami yang berasal dari hasil campuran bahan tanaman herbal. Bawang putih (Allium sativum) mengandung antioksidan yang dapat mendukung mekanisme pelindung tubuh dan dapat dimanfaatkan sebagai terapeutik (Prasonto dkk., 2017). Jahe (Zingiber officinale) mengandung senyawa volatile dan non volatile yang terdiri dari berbagai senyawa flavonoid dan polifenol yang mempunyai aktivitas antioksidan tinggi untuk mencegah adanya radikal bebas dalam tubuh (Supriyanti, 2015). Begitu pula buah lemon (Citrus limon L) juga memiliki kandungan bioflavonoid, polifenol, kumarin yang memiliki manfaat sebagai antioksidan alami (Nizhar, 2012).

Kandungan senyawa vitamin C, asam sitrat, minyak atsiri, bioflavonoid, polifenol, kumarin, flavonoid, dan minyak-minyak volatil yang terkandung di dalam bahan tanaman dapat menangkal stres oksidatif ditubuh manusia dengan cara membantu mempertahankan keseimbangan antara oksidan dan antioksidan. Stres oksidatif adalah suatu keadaan ketika kandungan oksidan dan radikal bebas di dalam tubuh lebih banyak dibandingkan antioksidan (Mateen et al., 2016).

Antioksidan adalah senyawa yang mampu menunda, memperlambat dan mencegah proses oksidasi lipid. Dalam arti khusus antioksidan adalah zat yang dapat menunda atau mencegah terjadinya reaksi radikal bebas dalam oksidasi lipid (Ahmad dkk., 2012). Sumber antioksidan dapat diperoleh secara alami dan sintetik. Antioksidan alami merupakan senyawa antioksidan yang terdapat secara alami dalam tubuh sebagai mekanisme pertahanan tubuh 
normal maupun berasal dari asupan luar tubuh. Antioksidan sintetik merupakan senyawa yang disintesis secara kimia. Antioksidan alami dari dalam tubuh yang dihasilkan tidak cukup untuk melawan radikal bebas di dalam tubuh yang berlebih, untuk itu diperlukan masukan antioksidan dari luar tubuh (Winarsi, 2007).

Maka oleh sebab itu, pengabdian ini memaggunakan suplemen herbal yang terbuat dari bawang putih, jahe, madu dan lemon. Pedagang harus di sosialisasikan tentang pentingnya suplemen herbal ini agar mereka tetap bugar dan sehat pada saat pandemi Covid 19. Pedagang akan diajarkan cara meracik bahan-bahan tersebut untuk dijadikan suplemen herbal.

Hartati et al (2021) telah sukses dalam melakukan pengabdian dengan tentang keterlibatan mahasiswa dan akademisi dalam pengabdian masyarakat menghadapi pandemi covid-19. Fitriana et al (2021) juga telah melakukan pengabdian tentang pelatihan protokol kesehatan bagi pemandu wisata pedesaan di Kabupaten Belitung. Desmira (2021) telah sukses dalam melakukan pengabdian Sosialisasi dan Edukasi Protokol Kesehatan Bagi Masyarakat Desa.

Athaillah \& Husin (2021) juga telah melakukan pengabdian tentang edukasi pemanfaatan limbah sisa makanan menjadi produk yang bernilai ekonomis.

\section{METODE}

Adapun Metode pelaksanaan Pengabdian adalah sebagai berikut:

1. Sosialisasi tentang covid 19 dan pencegahannya dengan menguatkan imun

Sosialisasi tentang covid 19 akan disampaikan oleh beberapa narasumber dari Dinas Kesehatan Aceh Barat.

2. Sosialisasi pentingnya meminum suplemen herbal kepada pedagang

Sosialisasi akan dilaksanakan dengan cara menjumpai setiap pedagang dikota Meulaboh. Sosialisasi dengan cara seperti ini dilakukan untuk menghindari kerumunan yang disengaja maupun kerumunan yang tidak disengaja yang bisa memperparah keadaan ditengah pandemi covid 19.

Pedagang yang akan di sosialisasi pentingnya meminum suplemen herbal berjumlah 40 orang. Setiap pedagang diajak untuk rutin membuat dan meminum suplemen herbal yang terbuat dari Jahe, Madu, Lemon dan bawang putih. Pedagang juga akan diberikan bantuan Jahe, Madu, Lemon dan bawang putih.

3. Proses Pembuatan suplemen herbal

Adapun bahan yang diperlukan untuk pembuatan suplemen herbal adalah :

- Jahe

- Bawang putih

- Lemon

- Madu

\section{HASIL DAN PEMBAHASAN}

Kegiatan pengabdian dimulai dari dilakukan survey lapangan oleh tim kepada para pedagang sayur dan pedagang kaki lima yang berjualan di kota Meulaboh. Dari hasil peninjauan lapangan ada 2 orang yang di jadikan mitra untuk mensukseskan kegiatan pengabdian yang dilakukan. Mitra membantu penyediaan tempat, mitra juga membantu mengajak para pedagang lainnya untuk mengikuti pengabdian dan memfasilitasi antara pengabdi dengan para pedagang. Kegiatan pengabdian mulai dari survey lapangan hingga selesai pembuatan laporan akhir adalah 5 bulan, yang dimulai dari bulan Maret.

Setelah dilakukan survey dan mendapatkan mitra, pengabdi mengundang 2 orang narasumber dari Dinas Kesehatan Aceh Barat. Narasumber diundang untuk melakukan sosialisasi tentang covid 19 dan pencegahannya dengan menguatkan imun tubuh menggunakan ramuan herbal. Para pedagang diedukasi untuk selalu menjaga diri dan keluarga agar terhindar dari covid 
19 dengan cara selalu mentaati protokol kesehatan. Para pedagang diedukasi untuk selalu menggunakan masker dan menjaga daya tahan tubuh.
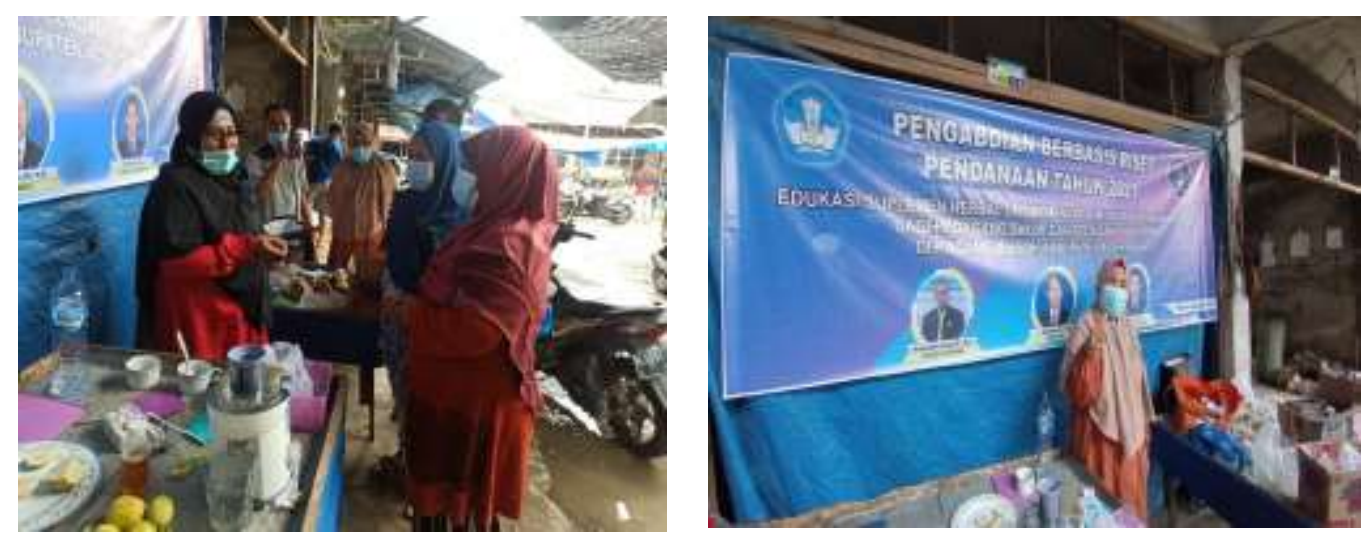

Gambar 1. Sosialisasi tentang covid 19 dan pencegahannya dengan menguatkan imun

Setelah dilakukan sosialisasi tentang covid 19 dan pencegahannya, berikutnya dilakukan sosialisasi tentang suplemen herbal untuk meningkatkan imun dan daya tahan tubuh. Sosialisasi ini bertujuan untuk mengedukasi pedagang tentang pentingnya suplemen herbal. Sosialisasi ini juga untuk mengajak pedagang agar membuat dan menkonsumsi supleman herbal yang telah dibuat.

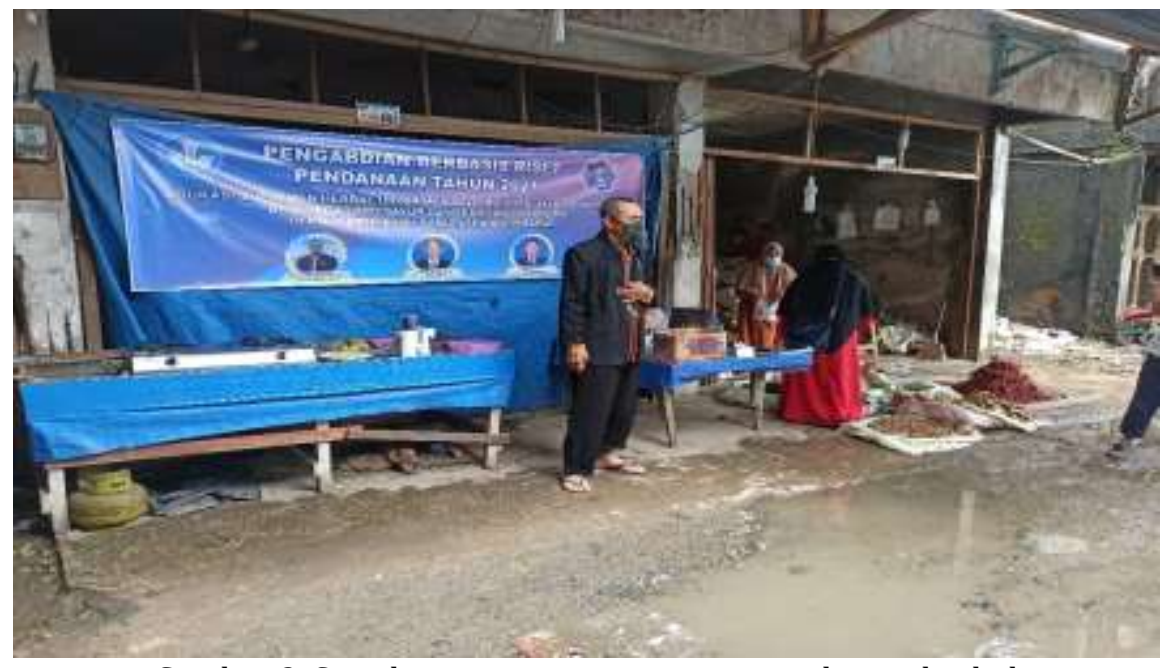

Gambar 2. Sosialisasi tentang pentingnya suplemen herbal

Setelah sosialisasi selesai, kemudian dilakukan edukasi tentang pembuatan dan pengolahan suplemen herbal untuk meningkatkan daya tahan tubuh dengan bahan jahe, bawang putih, lemon dan madu. Pembuatan suplemen tersebut dilakukan langsung dengan 2 cara, cara yang pertama hanya dengan di blender dan langsung bisa diminum. Cara yang kedua adalah dengan di kukus terlebih dahulu sebelum di blender dan disajikan. Untuk takaran formula suplemen yang 
digunakan untuk sekali konsumsi adalah: $1 \mathrm{ml}$ ekstrak bawang putih, 2,5 ml ekstrak jahe, 2,5 ml ekstrak jeruk lemon dan $10 \mathrm{ml}$ madu.
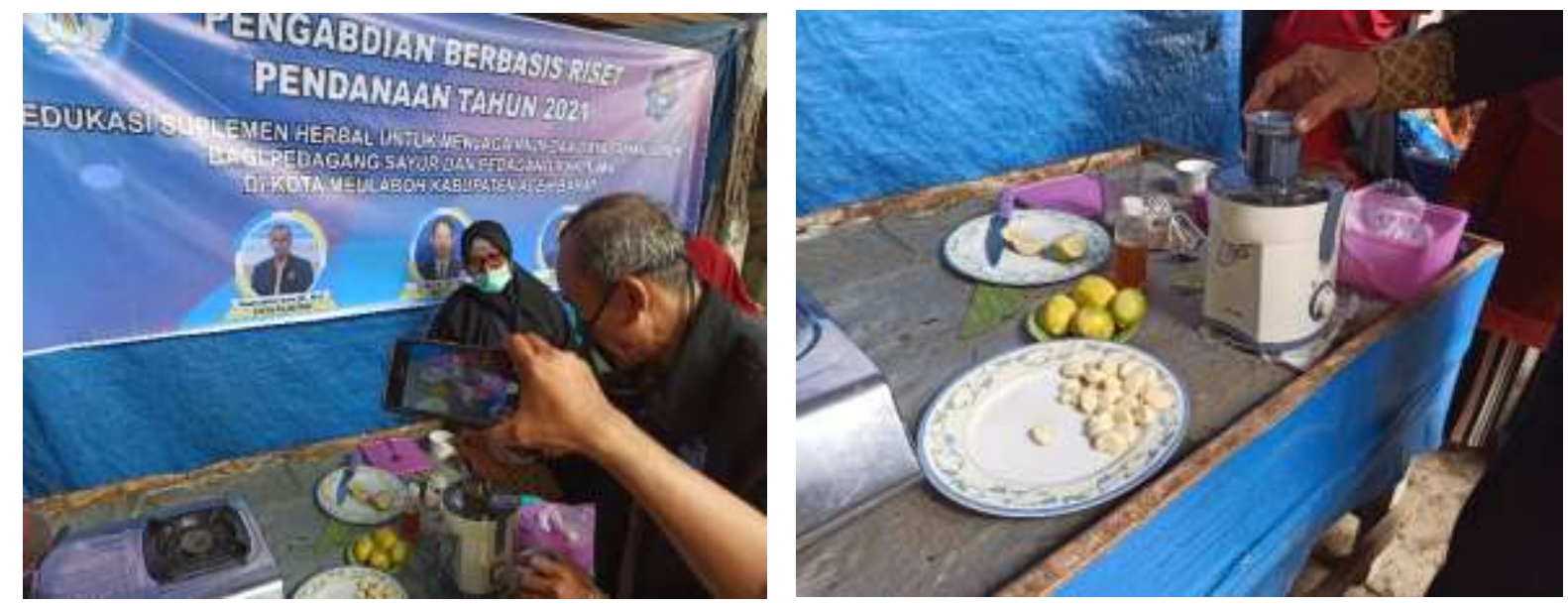

Gambar 3. Proses pembuatan suplemen herbal tanpa di kukus

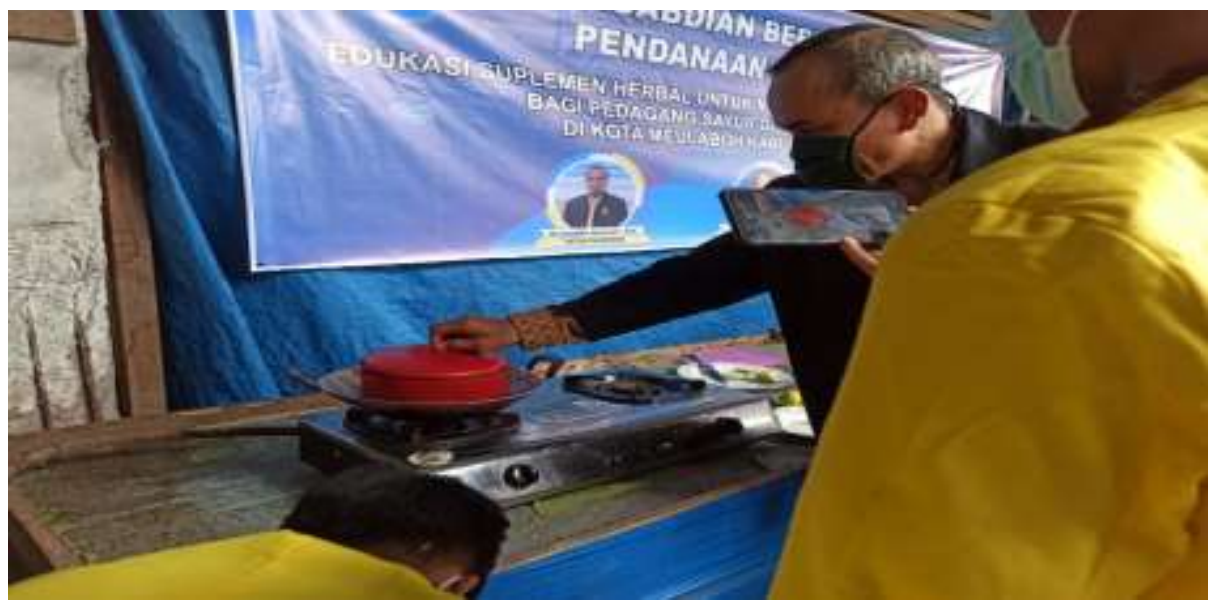

Gambar 4. Proses pembuatan suplemen herbal dengan di kukus

Setelah dipraktekkan langsung didepan para pedagang, bagi pedagang yang ingin bertanya dan melakukan diskusi di izinkan untuk maju dan melihat langsung produk yang telah jadi. Banyak pedagang yang memberi respon positif terhadap produk yang telah dibuatkan. Ditinjau dari segi rasa, para pedagang lebih menyukai suplemen yang telah dikukus. Rasa suplemen yang belum dikukus terasa lebih pahit.
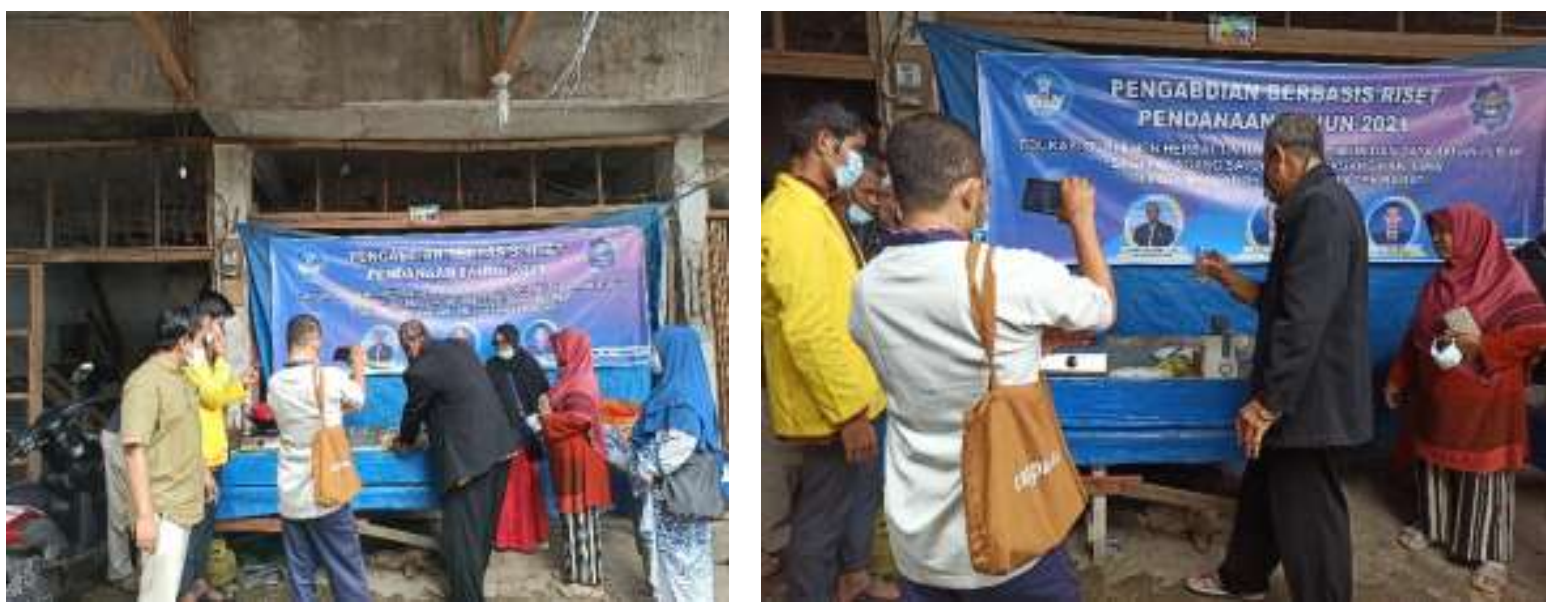

Gambar 5. Pedagang diberi kesempatan untuk melihat langsung 
Setelah dibuatkan suplemen herbal, agar program terus berlanjut dan pedagang mencoba untuk membuatnya dirumah, maka dilakukanlah pembagian bahan baku kepada para pedagang. Bahan baku yang diberikan kepada para pedagang diperkirakan bisa untuk 15-20 hari produksi. Bahan baku tersebut dibagikan kepada 40 orang.
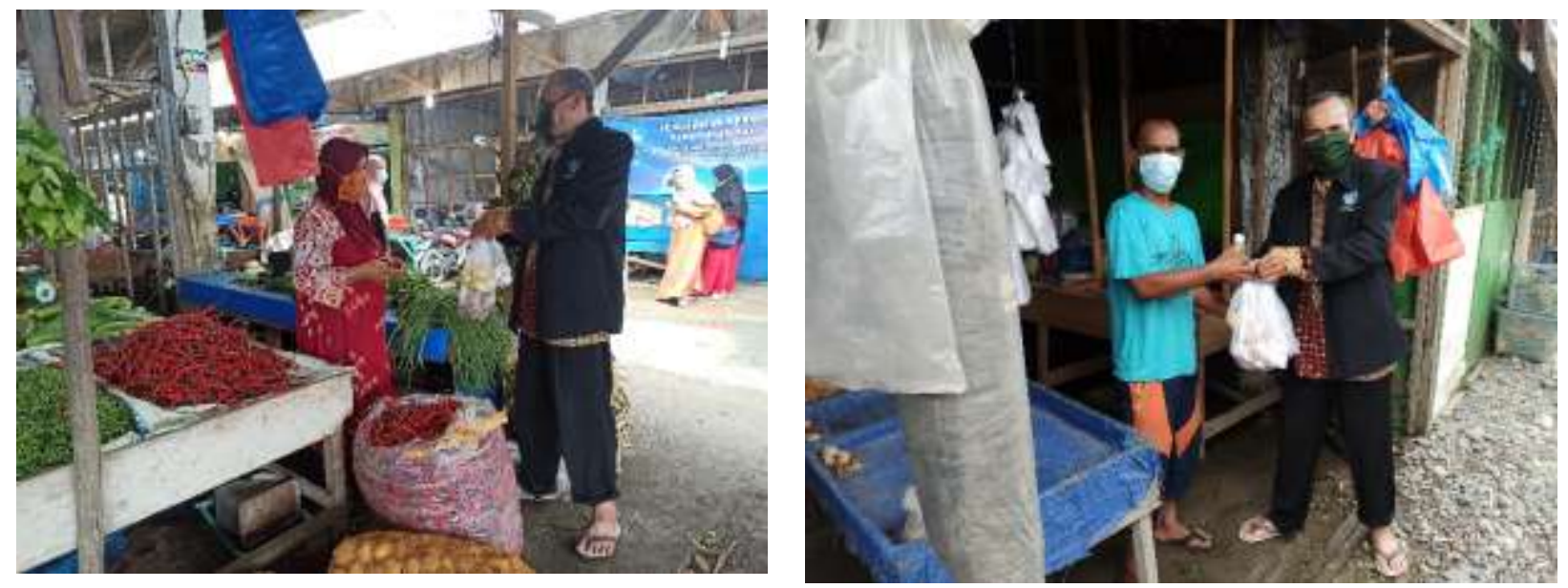

Gambar 6. Pembagian bahan baku suplemen herbal

Respon dan Tanggapan Khalayak Sasaran

Masyarakat menyambut baik pengabdian ini. Para pedagang sangat antusias dan ingin membuat suplemen herbal dirumah. Antusias pedagang juga terlihat dari keingintahuan pedagang tentang cara pembuatan suplemen herbal. Program pengabdian ini tentunya sangat bermanfaat bagi para pedagang untuk menjaga imun dan daya tahan tubuh pada saat pandemi covid 19 melanda.

\section{KESIMPULAN}

1. Pengabdian pembuatan suplemen herbal sukses dilakukan di kota Meulaboh

2. Para pedagang sangat terbantu dengan diadakan pengabdian pembuatan suplemen herbal

3. Para pedagang sangat antusias dan ingin membuat suplemen herbal dirumah

\section{UCAPAN TERIMA KASIH}

Penulis mengucapkan terima kasih kepada Universitas Teuku Umar yang telah memberi dukungan financial terhadap pengabdian ini melalui Hibah Internal Sumber Dana PNPB Universitas Teuku Umar.

\section{DAFTAR PUSTAKA}

Ahmad, R., Munim, A. dan Elya, B. 2012. Study of Antioxidant Activity With Reduction of Free Radical DPPH and Xanthine Oxidase Inhibitor of the Extract Ruellia tuberosa Linn Leaf. International Research Journal of Pharmacy 3(11).

Athaillah, T., \& Husin, H. (2021). Edukasi Pemanfaatan Limbah Sisa Makanan Menjadi Produk Yang Bernilai Ekonomis. Dinamisia: Jurnal Pengabdian Kepada Masyarakat, 5(2), 437-442. https://doi.org/10.31849/dinamisia.v5i2.5262

Desmira. 2021. Sosialisasi dan Edukasi Protokol Kesehatan Bagi Masyarakat Desa. Dinamisia: Jurnal Pengabdian Kepada Masyarakat, 5(2), 408-412. 
Fitriana R., Tarunajaya W.B., Akbar K. (2021). Pelatihan Protokol Kesehatan Bagi Pemandu Wisata Pedesaan di Kabupaten Belitung. Dinamisia: Jurnal Pengabdian Kepada Masyarakat, 5(3), 608-616.

Hartati, S., Syamsuadi, A., Elvitaria, L. (2021). Keterlibatan Mahasiswa dan Akademisi dalam Pengabdian Masyarakat Menghadapi Pandemi Covid-19. Dinamisia: Jurnal Pengabdian Kepada Masyarakat, 5(2), 474-480.

Mateen, S., Moin, S., Khan, A.Q., Zafar, A. dan Fatima, N., 2016. Peningkatan Pembentukan Spesies Oksigen Reaktif dan Stres Oksidatif pada Rheumatoid Arthritis. PloS satu 11(4).

Nizhar, U. 2012. Level Optimum Sari BuahLemon (Citrus Limon) SebagaiBahan Penggumpal Pembuatan KejuCottage. Skripsi. FakultasPeternakan, Universitas Hasanuddin. Makassar.

Prasonto, D., Riyanti, E. dan Gartika, M. 2017. Uji Aktivitas Antioksidan Ekstrak Bawang Putih (Allium sativum). ODONTO Dental Journal 4 (2) : 122-128.

Supriyanti, H. 2015. Untung Besar Budidaya Jahe Merah. Araska. Yogyakarta.

Winarsi, H. 2007. Antioksidan Alami dan Radikal Bebas. Penerbit Kanisius. Yogyakarta. 